\title{
Physics, Chemistry and Application of Nanostructures
}

Review and Short Notes to Nanomeeting '97 
This page is intentionally left blank 


\title{
Physics, Chemistry and Application of Nanostructures
} Review and Short Notes to Nanomeeting '97

\author{
Minsk, Belarus $\quad 19-23$ May 1997
}

\author{
Editors \\ V. E. Borisenko \& A. B. Filonov \\ Belarusian State Univ. of Informatics \& Radioelectronics, Minsk
}

S. V. Gaponenko
Stepanov Inst. of Physics, Minsk
V. S. Gurin
Belarusian State Univ, Minsk 


\section{Published by}

World Scientific Publishing Co. Pte. Ltd.

P O Box 128, Farrer Road, Singapore 912805

USA office: Suite 1B, 1060 Main Street, River Edge, NJ 07661

UK office: 57 Shelton Street, Covent Garden, London WC2H 9HE

\section{British Library Cataloguing-in-Publication Data}

A catalogue record for this book is available from the British Library.

\section{PHYSICS, CHEMISTRY AND APPLICATION OF NANOSTRUCTURES}

Review and Short Notes to Nanomeeting ' 97

Copyright $\odot 1997$ by World Scientific Publishing Co. Pte. Ltd.

All rights reserved. This book, or parts thereof, may not be reproduced in any form or by any means, electronic or mechanical, including photocopying, recording or any information storage and retrieval system now known or to be invented, without written permission from the Publisher.

For photocopying of material in this volume, please pay a copying fee through the Copyright Clearance Center, Inc., 222 Rosewood Drive, Danvers, MA 01923, USA. In this case permission to photocopy is not required from the publisher.

ISBN $981-02-3113-X$

This book is printed on acid-free paper.

Printed in Singapore by Uto-Print 


\title{
INTERNATIONAL CONFERENCE
}

\author{
NANOMEETING-97 \\ Minsk, Belarus, May 19-23, 1997
}

\begin{abstract}
ORGANIZERS
Ministry of Education and Science of Belarus

Belarusian State University of Informatics and Radioelectronics Belarusian State University
\end{abstract}

\section{Academy of Sciences of Belarus}

Department of Physics, Mathematics and Informatics Institute of Physics of Solid State and Semiconductors

Stepanov Institute of Physics Institute of Electronics

Department of Physical and Technical Problems of Energy Supply

Physical Technical Institute

\section{SPONSORS}

Basic Research Foundation of Belarus Association of Novel Materials and Technologies «NOMATECH» Belarusian Fund of Informatization Belarusian Soros Foundation 


\title{
INTERNATIONAL ADVISORY BOARD
}

\author{
E.V. Buzaneva \\ J. Derrien \\ L. W. Molenkamp \\ H. Morisaki \\ V.A. Pilipovich \\ M.V. Ramakrishna \\ C.M. Sotomayor Torres \\ V.V. Sviridov \\ K.A. Valiev
}

(Ukraine)

(France)

(Germany)

(Japan)

(Belarus)

(USA)

(UK)

(Belarus)

(Russia)

\section{INTERNATIONAL ORGANIZING COMMITTEE}

V.E. Borisenko - Chairman

F. Arnaud d'Avitaya

M.-J. Cantow

F.F. Komarov

A.A. Kovalev

$H$. Lange

N.M. Olekhnovich

A.P. Voitovich
(Belarus)

(France)

(Germany)

(Belarus)

(Belarus)

(Germany)

(Belarus)

(Belarus)

\section{NATIONAL ORGANIZING COMMITTEE}

\section{V.M. II'in - Chairman}
A.I. Belous
V.I. Kuvshinov
A.M. Chaplanov
V.K. Solonovich
A.B. Filonov
S.V. Gaponenko
G.V. Petrov
V.S. Gurin
A.N. Govaydinov
I.E. Tralle




\title{
PREFACE
}

This book collects invited reviews and short notes of submitted contributions selected by the International Advisory Board for presentation at the International Conference NANOMEETING- 97 . They are arranged in sections: Physics of Nanostructures, Chemistry of Nanostructures, Nanotechnology, and Nanosize Optical and Electronic Devices. Basic and applied researches in these exiting areas are explosively increased worldwide. That is why a reader is free of any pressure with a dominant point of view and promising trends while some prospects are already stressed in the particular papers. All of them are for personal analysis and conclusions. We have mainly preserved original style of the papers. Please consider them as preprinted notes showing the most important recent results supposed to be focused and discussed at the Conference.

I have a pleasure to thank all the contributors of NANOMEETING-97 for enhancing our understanding of the nanoworld. The Sponsors provided the financial background for that are acknowledged.

\author{
Victor E. Borisenko \\ Chairman of NANOMEETING-97 \\ Minsk, February 1997
}


This page is intentionally left blank 


\section{CONTENTS}

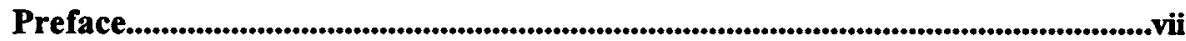

\section{PHYSICS OF NANOSTRUCTURES}

Recent progress in light emitting $\mathrm{Si} / \mathrm{CaF}_{2}$ multiquantum wells.......................................3

F. Amaud d' Avitaya, F. Bassani , I. Mihalcescu, A. G. Nassiopoulos

Light-emitting II-VI nanostructures .........................................................................................18

M. Heuken, H. Kalisch, H. Hamadeh

Films with high concentrations of quantum dots.

A.P. Voitovich, O.V. Goncharova

Germanium nanostructures deposited by the cluster-beam evaporation technique

Shinji Nozaki, Seiichi Sato, Hiroshi Ono, Hiroshi Morisaki

Radiation effects in Si/Ge nanostructures.........................................................................43

N.A. Sobolev

$\mathrm{SiO}_{2} / \mathrm{TiO}_{2}$ submicron 3D lattice: a new step towards visible - range photonic crystals.

A.M. Kapitonov, N.V. Gaponenko, V.N. Bogomolov,

A.V. Prokofiev, S.M. Samoilovich, S.V. Gaponenko

Strong room-temperature photoluminescence of $\mathrm{Er}-\mathrm{Yb}$ compleres embedded in porous silicon .58

V. Filippov, P. Pershukevich, V. Homenko, V. Bondarenko, M. Balucani, A. Ferrari

Measurement and simulation of refractive index profiles of ultrathin silicon dioxide film. .61

Y.-B. Wang, P. Han, Q. Chen, M. Willander 
Optical properties modifications of porous silicon by surface chlorination under ultrahigh vacuum..

K.N. Eltsov, V.A. Karavanskii, V.V. Martynov

Investigation of the influence of $\mathrm{GeH}_{3}$ molecule disintegration kinetics on abruptness of $\mathrm{Ge}$ composition at $\mathrm{Si}_{1-\mathrm{x}} \mathrm{Ge}_{\mathbf{x}} / \mathrm{Si}$ interface in $\mathrm{Si}-\mathrm{GeH}_{\mathbf{4}} \mathrm{MBE}$

A.V. Potapov, L.K. Orlov

Three types of spectral hole - burning in CdS nanocrystals

S.V. Gaponenko, I.N. Germanenko, A.M. Kapitonov,

U. Woggon, $O$. Wind, C. Klingshim

New explanation of anomalous degradation of GaAs quantum well lasers. .78

M.E. Polyakov

Optically controlled tunneling in double-barrier heterostructure AlAs/GaAs .83

S.A. Vitusevich, A.E. Belyaev, T. Figielski, R.V. Konakova, A. Makosa

Reflectance and electroreflectance of MBE grown GaN layers .87

S.V. Shokhovets, R. Goldhahn, G. Gobsch, T.S. Cheng, C.T. Foxon

Thin solid films of closely-packed CdS nanocrystals as media for holographic grate writing .91

Yu.P. Rakovich, E.A. Lutsenko, A.A. Gladuyschcuk, M.V. Artemyev

Optical properties of nanoparticles prepared by a laser vaporization-controlled condensation technique

Shoutian Li, M. Samy El-Shall

Radiative recombination in $\mathrm{ZnMgSSe} / \mathrm{ZnSSe} / \mathrm{ZnSe}$ multiple quantum wells. .98

A.L. Gurskii, E.V. Lutsenko, V.N. Yuvchenko, G.P. Yablonskii, H. Hamadeh, J. Söllner, H. Kalisch, M. Heuken

Dimensional crossovers in superconductor - spin glass nanostructures .102

S.L. Prischepa, C. Attanasio, C. Coccorese, L. Maritato, M. Salvato, A.N. Lykov 
Energy structure of $\mathrm{Si}_{12}$ cluster .106

A.I. Bibik

Si (111) surface electronic structure in the vicinity of adsorbed $\mathrm{Li}$ atom.

E.F. Kislyakov, A.V. Yukhnevich

On modeling of electronic and photoelectronic processes in nanostructures A.A. Khodin

Carrier transport effect on a large signal response of quantum-well lasers with a saturable absorber.

S.V. Voitikov, V.P. Gribkovskii

Variation of the potential relief and emission spectra in doping superlattices under excitation

D.V. Ushakov, V.K. Kononenko

Simple approach to calculate band gap renormalization in semiconductor quantum wells

N.A. Poklonski, A.I. Siaglo

Electronic properties and overlap integral matrix calculation accuracy for silicon-based structures

V.A. Novikov, A.N. Kholod, A.V. Novikov, A.B. Filonov

Shot noise reduction in long mesoscopic wires

M. Henny, H. Birk, R. Huber, C. Schönenberger

Optical properties of fractal clusters

B.Sh. Galyamov, A.A. Lushnikov, V.V. Maksimenko, P.P. Maltsev, M.Yu. Yablokov

Magnetoresistance behaviour simulation in quantum wires

D. Domanevskij, S. Nikitin, T. Nikitina 


\section{CHEMISTRY OF NANOSTRUCTURES}

Formation and characterization of CdS nanoparticles in aqueous solution 145

Yoshio Nosaka

AFM and STM studies of Langmuir-Blodgett films of long-chain acids deposited from ionic subphases. 153

V.E. Agabekov, G. Bar, V.S. Gurin, G.K. Zhavnerko, T.A. Kuchuk

H.-J Cantow, V.S. Soldatov, I.V. Yaminsky

Spatially confined fractals

V.S. Gurin, V.P. Poroshkov

On the problem of evaluating adhesion of oxide coatings on metals.

V. Glyabin, L. Svirko, L. Lynkov, A. Gurov, N. Petrov, V. Zacharov, I. Boldysheva

Silver halide photographic layer as nanostructured system. 163

V.V. Sviridov, G.A. Branitsky, S.K. Rachmanov, V.D. Stashonok, A.L. Rogach

Strong $1.53 \mu \mathrm{m}$ luminescence from erbium-containing nanoclusters in sol-gel derived oxide films

N.V. Gaponenko, A.V. Mudryi, O.V. Sergeev, V.E. Borisenko,

E.A. Stepanova, A.S. Baran, A.I. Rat'ko, S.V. Baran, J.F. McGilp

Synthesis and characterization of CdTe nanoclusters in aqueous solutions 173

A.L. Rogach, L. Katsikas, A. Kornowski, Dangsheng Su, A. Eychmüller, H. Weller

Optical properties of multilayer CdSe/polymer structures

V.P. Red'ko, A.I. Voitenkov, O.E. Kovalenko

Synthesis of titanium dioxide hydrosol nanoparticles with different structures. .182

O.B. Pavlova-Verevkina, V.V. Nazarov, A.V. Pertsov 
Nanostructured mixed solids in tin and titanium oxides films:

synthesis, structure, and properties.

O. Morosova, G. Postovalova, S. Zavjalov, B. Galyamov, Yu. Roginskaya

Nonlinear phenomena in the reactions catalyzed by metal nanostructures. 188 G.A. Ragoisha

Nanoscale regions in solid solutions based on $\mathrm{PbZrO}_{3}$

E. D. Politova, S. E. Aksenov, E. V. Lovkova, V.V. Shvartsman, S. Yu. Stefanovich, L. Ya. Karpov

Novel method of preparing transparent thin films of $\mathrm{Pb}\left(\mathrm{Zr}_{1-\mathrm{x}} \mathrm{Ti}_{\mathbf{x}}\right) \mathrm{O}_{3}$ using sol-gel process.

S.K. Poznyak, N.A. Shkorik, L.S. Ivashkevich, A.I. Kulak

Synthesis of Q-sized metal sulphides in the electropolymer matrix.

N. Gaponik, D. Shchukin, A. Kulak, D. Sviridov

Formation of nanostructured Ge films by the low-temperature reduction of $\mathrm{GeO}_{2}$ and their optical properties.

G.P. Shevchenko, L.T. Potapenko

Nanostructured copper phthalocyanine-polyimide composites prepared by vacuum deposition

G.G. Fedoruk, D.I. Sagaidak, B.G. Shulitzki

Adsorption - resistive properties of copper phthalocyanine nanoaggregates in polymer matrix

G.G. Fedoruk, A.V. Misevich, A.E. Pochtenny, D.I. Sagaidak

\section{NANOTECHNOLOGY}

The possibilities of scanning microscopy techniques for the characterisation of semiconductors and devices.

L.J. Balk 
Chemical synthesis of nanostructures on the basis of scanning probe fabrication........220 Hiroyuki Sugimura

Inverse scattering problem method and quantum well engineering. .230

I.E. Tralle

Aluminium - porous silicon contact electrical characterization.

S. La Monica, S.A. Volchek, N.N. Vorozov, A. Caracciolo, A. Ferrari

Laser fabrication of light emitting structures based on porous silicon . .238

Yu.E. Babanov, E.Yu. Buchin., A.V. Prokaznikov, V.B. Svetovoy

On molecular porosity of Langmuir-Blodgett type films local structure taken with STM

H.-J. Cantow, G. Bar, V.K. Solonovich, L.V. Kukharenko,

N.A. Korbut, O.M. Stukalov, V.S. Soldatov, V.E. Agabekov

Fabrication and STM / STS study of nanostructure with single fullerene molecule.

V.I. Panov, V.V. Kolesov, E.A. Fedorov

Fullerenes as imaging elements of the atomic force microscope.

G.V. Dedkov

Silicon monocrystalline probes for STM and AFM

A.V. Yukhnevich, A.F. Novik, I.Y. Demesh

STM (AFM) tip testing by Rutherford backscattering. . .255

G.V. Dedkov, S.Sh. Rekhviashvili

Nanotechnology and nucleation rate fluctuations

D. Kane, S.P. Fisenko, M.S. El-Shall

Phase formation in iron nanolayers during successive boron and nitrogen high-dose implantation.

V.V. Uglov, J.A. Fedotova, V.V. Khodasevich 
The technology of direct formation of InAs/GaAs nanostructures during molecular beam epitaxy and related techniques.

V.N. Petrov, N.K. Polyakov, N.P. Korneeva, V.N. Demidov, S. Ya. Tipissev,

A.O. Golubok, V.G. Dubrovskii, G.E. Cirlin, N.N. Ledentsov, D. Bimberg

Preparation of ultrafine $\mathrm{PbCrO}_{4}$ particles in oxide matrices .269

G.P. Shevchenko, Z.M. Afanas'eva, V.V. Sviridov, M.V. Baykov

\section{NANOSIZE OPTICAL AND ELECTRONIC DEVICES}

Modern trends in nanoelectronic devices .273

J. Derrien

Technology and performance of diamond field emitters 283

V. Raiko, J. Engemann

Integrated "optical waveguide - photodetector" structures for $\mathrm{Si}$ optoelectronics

V.P. Bondarenko, A.M. Dorofeev, N.M. Kazuchits, G. Maiello, G. Mazini, A. Ferrari

Nanodimensional field emitter arrays based on porous anodic alumina 297

S. Zakhvitcevich, A. Govyadinov

Zero-dimensional thin film systems for optical applications. 301

O. Goncharova

Humidity sensors based on aluminum and nanoporous anodic alumina thin film interdigitated pattern.

V.F. Surganov, S.K. Metto

Nanoporous aluminium anodic oxide membrane. .306

V.F. Surganov, G.G. Gorokh

Beam instability caused by the electron injection out of QW into 2DEG .309 I.E. Tralle, V.A. Sizjuk 
Coherent transport in MIS nanostructures

I.I. Abramov, A.L. Danilyuk

Nanoelectronic device simulator Nanodev

E.G. Novik, I.V. Sheremet, S.S. Ivashkevich, I.I. Abramov

Electronic devices based on quantum wires: Prospects and problems........................322

I.A. Obukhov

Simulation of scattering effects in a double-barrier resonant tunneling

diode by means of the Monte Carlo method

V.M. Borzdov, F.F. Komarov, M.M. Vrubel, A.V. Homich

Application of porous silicon in diamond coated silicon emitters

V. Raiko, D. Theirich, J. Engemann

Author Index 